\title{
Creator or author. Norwid's concept of beauty, art and artist or the arts creating process
}

The Christian concept of beauty, art, an artist formulated by C.K. Norwid and presented in his Promethidion, clearly refers to the experience of fine arts. The reference to the arts-creating process makes and blends together Norwid's concept.

In order to formulate the definition of beauty, Norwid uses three terms: shape, profile and form. In fine arts these terms have specific meanings, they relate to one another, defining particular stages of a process of creation. Understanding the form as a matrix seems to be significant in Norwid's concept. It allows seeing the man's work as an image of God's act of creation. Humans, created in the image and likeness of God, are capable of creating. We were invited to create beauty and good and thanks to them we discover God as the source of transcendent values and we get close to Him.

Key words: beauty, good, truth, love, art, Creator, author, artist, conjurer, creating process, shape, profile, form, matrix, repetition, reflection, cognition, resurrection, the secret of creation, the secret of incarnation, likeness of God.

Cyprian Kamil Norwid (1821-1883) an artist, poet, thinker, as John Paul II wrote, left a work which emanates light, which allows us to go deeper into the truth of our being humans, Christians, Europeans, Polish people ${ }^{1}$. His mastery of the word, the beauty of his language, creative use of and building semantic or sound nuances make Norwid's

Jan Paweł II, Z poezji Norwida emanuje światto, [Norwid's poetry emanates light], a speech given to representatives of National Heritage Board of Poland on C.K. Norwid's180 $0^{\text {th }}$ birth anniversary, http://www.opoka.org.pl/zycie kosciola/ l'osservatore romano/ 9(236)2001/ kosciol w polsce. Html (10 Feb 2017) 
Theology of beauty

work seemingly hermetic and rather difficult to translate. And yet, his ideas concerning esthetics, social or theological issues are characterised by universalism which reaches far beyond nationality. John Paul II referred to Norwid as one of the greatest poets and thinkers of Christian Europe ${ }^{2}$. His work involves numerous areas of activity, inspires to carry out various studies and amazes with its timeless message.

A question could be asked: why does an architect, an interior designer, want to read a poem instead of talking about architecture and the space of sacredness, which they deal with daily?

Certainly, a personal relation to Norwid's poetry, dating back to my youth thanks to my Parents, plays a significant role here. However, it is the work of Cyprian Kamil Norwid, an artist, and as we would say today, a fine artist educated at various Academies of Fine Arts, who lived off art, that invites to do this non-philological research.

In the poet's work, where he "wrote with one hand and drew and painted with the other" 3 a romantic idea of arts coexistence materialized, as "thinking, a man paints and sings at the same time" ${ }^{4}$. Although time has shown that, as Horace said, the word is more durable than sculptures of bronze or oil paintings, undoubtedly, for understanding art, an artist's role and work and to create a theoretical aesthetical concept, Norwid's own artistic experience had a vital meaning. That experience gave a wider perspective and allowed understanding nuances resulting from a different methodology of work, technique or sensitivity.

Following that trail, one could presume that to read and grasp Norwid's concept presented in his Promethidion, one's own artistic experience as well as knowledge about the artistic creative process may appear helpful.

This text is an attempt to emphasize those motifs which point at a connection between Norwid's theory and experience of fine arts.

$$
* * * *
$$

Kształtem miłości piękno

$$
\text { jest - i tyle, [Beauty is a form of love }
$$

Ile ją człowiek oglądał na świecie, As much a man has seen it in the world, W ogromnym Bogu albo w sobie-pyle, In the great God or himself - the dust,

Ibidem.

3 Norwid, C.K.List do Teofila Lenartowiczaz 16 X 1868, Pismawszystkie, [A Letter to Teofil Lenartowicz] worked out by J.W. Gomulicki, 1971-1976, IX pp. 371-37. (All quotations translated by A.J.)

$4 \quad$ Ibidem, Rzecz o wolności stowa, [About Freedom of Speech] III p. 582. 
Na tego Boga wystrojonym dziecię Tyle o pięknem wie i głosiChoć każdy w sobie cień pięknego nosi I każdy - każdy z nas - tym piękna pyłem ${ }^{5}$.
A child dressed up as the God knows and tells as much about beauty Although everyone has a shade of beauty inside And every one of us - is the beauty's dust.]

A starting point for the reflection and at the same time a basis for Norwid's concept of beauty, art and artistic work is the biblical truth that God created man in the image and likeness of Him. Stefan Sawicki remarks that together with man real art begins and the art remains in the circle of beauty, it starts as an effect of love's embodiment, as a necessary foundation where beauty finds its vital fundament ${ }^{6}$. Beauty begins where love gains a form, where it is embodied in some material ${ }^{7}$.

One could observe that another mainstay of Norwid's concept is the mystery of incarnation. Both mysteries: of the beginning of the Old Testament and the beginning of the New Testament interpenetrate each other and have many common points. Beauty becomes a shape, belongs to incarnated Love:

I wszelka inna miłość bez wcielenia, [And any other love without

incarnation,

Jest upiorowym myśleniem

$$
\text { myślenia... }{ }^{8} \text { is ghostly thinking of thinking...] }
$$

Human ability to feel and create beauty, good and truth has its source in God, who is Beauty, Good and Truth, who made man capable of creating, as $\mathrm{He}$ is a perfect Creator. The Origin of all things. The Great Artist.

Norwid seems to go further and implies that if man, "the shadow of the beauty", had kept God's likeness in his conscience 9 , he would be able to create things far more perfect and closer to heaven:

Co się zachwyca w niebo:

szłaby dusza

tam - tam - a płótno na dół

by spadało,
[A soul that enchanted would go to heaven

there - there - and canvas would fall down, jako jesienny liść gdy dojrzy grusza ${ }^{10}$ like a dry leaf in autumn.] 
In the Gospel of St. Matthew Jesus said: "if you have faith as a grain of mustard seed, you will say to this mountain, 'Move from here to there,' and it will move."11 If a human being looked after God's trace in himself "through the sin lost in us shadows of profile"12,

A granitowi rzekł „Żyj jako żyłem”, [And said to granite „Live as I lived” to by się granit poczuł na wejrzeniu, Then the granite would feel it in its eyes

i może palcem przecierał powieki, And it might wipe its eyelids with

jak przebudzony mąż z ziemi

Like a man from a distant land its finger

woken up.]

Norwid may refer to the Gospel of St. Matthew directly, thinking about man's creativity and makes it dependent on cleanliness of one's conscience, therefore, not only faith but faithfulness, giving his aesthetical concept a moral dimension.

- Co piękne, nie jest to -

Co się podoba dziś lub

podobało,

Lecz co się winno podobać; But what I should like, as jak niemniej

I to, co dobre, nie jest, z czym przyjemniej,

Lecz co u leps s a ... ${ }^{14}$
[What is beautiful is not

What I like or liked,

What is good is not more pleasant

But what makes me better...]

Such thinking results in a belief that it is impossible to divide the values of beauty and good. Norwid describes good as "the other self of beauty" 15 . A reference to the Grecian kalokagatia is present in Norwid's concept, definitely permeated with Christian thought, symbolically expressed by the notion of Love, which unites beauty and good.

In his Introduction for Promethidion the poet calls:
O sztuko-wiecznej tęczo
[Oh Art, the rainbow of eternal
Jeruzalem,
Tyś jest przymierza łukiem -
po potopach
Historii ${ }^{16}$
Jerusalem, You are the bow of covenance - of History ]

\footnotetext{
11 All biblical quotations from: www.biblegateway.com

$12 \quad$ Ibidem, 157, p. 77.

13 Ibidem, 123-126, p. 77.

$14 \quad$ Ibidem, 50-54, p. 74.

15 Ibidem, compare: Bogumit 176-177, p. 79.

16 Ibidem, Wstęp, [Introduction] 11-12, p. 68.
} 
in reference to the Book of Genesis: "I have set my rainbow in the clouds, and it will be the sign of the covenant between me and the earth." (Gen 9,13). Grażyna Halkiewicz - Sojak points out that in Norwid's poem the rainbow is also a metaphore of art and the covenant between God and the world. She writes that such permeation of semantic fields implies that the art-rainbow intermediates between the human and divine dimentions of existence and is the work of an artist who can read God's signs ${ }^{17}$.

Art is certainly an artist's work. Creative work is an attribute of man but, paraphrasing what Jesus said to Pilate, man would have no power to create if it were not given from above. (compare John 19, 11). In his Sztuka dla Polaków [ Art for Polish People] Norwid wrote:

In ideal beauty-doing there is a feeling of superior order of things, to which rising, if at the top of it one cannot take the truth encountered, it is only because man can take nothing that was not at first given to him. ${ }^{18}$

The author of Promethidion however, understands the capability of creating or contemplates it not perhaps as a gift of the Creator but as likeness to the Creator. The likeness of the creative process and of the artistic one, their relationship, interpenetration and parallelism.

The concept of creationism perceives the act of creation as a singletime and completed work. In the Polish language the words creator and creature emphasize and sanction the character of that completedness. The word twórca, which in English is also "creator" and therefore in this text is translated as "artist" or "author", and tworzenie, which sounds very similar to „stworzenie”, i.e. creature, but actually means "making, composing", on the contrary, have the imperfect aspect and suggest duration, permanence. It could be agreed that, in the view of the previous consideration, art is a form of reading God's signs, a way of unveiling beauty, discovering, coming to know it. On the other hand, as St. Paul said, "we know in part and we prophesy in part (...) now we see only a reflection as in a mirror.." (1 Cor 13,$9 ; 12)$. Norwid's creative process is such a reflection in a mirror, repeating the process of God's creation. Each artistic act is a reflection of God's act of creation and the function of art is primarily revealing Beauty, Good, Love and Truth.

17 Halkiewicz-Sojak,Grażyna,: Norwidowskiemetaforyidefinicjepiękna,[Norwid's Metaphores and Definitions of Beauty] [in:] E. Nowicka i Z. Przychodniak (ed.), Piękno wieku dziewiętnastego. Studia i szkice z historii literatury i estetyki, [Beauty in the $19^{\text {th }}$ Century] Poznań 2008, p. 56.

18 Norwid, C. K.: O sztuce dla Polaków, [Of Art for Polish People] Pisma Wybrane. Worked out by J.W. Gomulicki, PIW 1968, IV, p. 369. 
Understanding creativity as a process of showing the reflection of perfection has its ancient roots. There is a Platonian idea in the verses of Promethidion. The author clearly points to collaterality of divine and human realities but those realities are not independent, they interpenetrate each other. The notions of Beauty, Good, Love and Truth, spelled with capital letters, refer to God's attributes, they are ideas which describe Him, whereas spelled with small letters are human merits, means used to present and come nearer to the divine ideal.

At the same time Norwid points to a reverse reaction on the one hand, an artistic act is an implication of the act of creation and is in a way inspired by the Creator Himself, but on the other hand it should be directed at the Creator by the artist. The artist in Norwid's opinion is first of all an apostle.

How to understand the parallelism of the act of creation and an artistic act?

Norwid built his concept on his experience of an artistic process. In order to recognize the stages of such a process, it is necessary to look at the definitions of beauty phrased by the poet. In Promethidion there are three definitions. The most frequently quoted is:

„Cóż wiesz o pięknem?..., „ .... „Kształtem jest Miłości”

[What do you know about beauty? It is a shape of Love]

This definition is usually cited in order to demonstrate the identical nature of beauty and Love. The word Love, written in a capital letter, undeniably refers to God the Creator, who is Love.

Another quasi definition:

Gdy jak o pięknem rzekłem - że jest profil Boży, ${ }^{20}$

[As when I said about beauty - it's God's prophile]

in a way completes the first one. It clearly emphasises that beauty is a shape, or rather a name or face (depending on how we intepret the word profile) of God.

The third definition, which chronologically appears as the earliest of explanations addressed Do Czytelnika [To the Reader] at the beginning of the dialogues. Perhaps it should also be viewed in the context of the explanations:

...idzie o formę to jest Piękno o treść, to jest Dobro, i o światłość

[...it's about the form, i.e. Beauty [about the content, i.e. Good

$19 \quad$ Norwid, C. K.: Promethidion, Bogumit. 109 p. 76.

$20 \quad$ Ibidem, 157, p. 78. 
obu Prawdę ${ }^{21}$ and the light of them both, Truth]

In this configuration appear three transcendent values, whereas the form, the content and the light are another, parallel conceptual level. ${ }^{22}$ The very definition of beauty which emerges from these words: ...forma to jest Piękno.

[the form is Beauty.]

underlines the transcendent dimension of beauty with using a capital letter, although deprived of its context seems to be less metaphorical and more literal. It is the simplest of definitions, too, also from the grammatical point of view.

It is possible to make similar grammatical simplifications of the sentences quoted above - in the statement "beauty is the shape of Love", when we omit the object, what is left is "beauty is the shape..."

Such a description again seems less metaphorical and in a way becomes similar to the third definition which has been mentioned, where beauty is perceived as a form. If another definition is simplified too, we get the notion of beauty described as a profile.

Thus, we receive three concepts which Norwid uses to describe beauty: the shape, the profile and the form.

These notions in colloquial language are used as synonyms. In the PWN dictionary of the Polish language the definitions of the profile and the form include the word "shape", whereas the shape is not described with words profile or form..$^{23}$. Consequently, the concept of shape seems primal to the other two. It is an important observation, because it brings us closer to the area of plastic arts, where these three notions can be used as very similar but not synonymous, and there are relations and dependences between them, as well as chronology.

In the first stage of an artistic act emerges the shape, it is abstracted by the artist with available means and tools. The shape is the original adumbration. The shape is materialization of the idea, its incarnation.

21 Ibidem, Do czytelnika [To the Reader] 15-16, p. 69.

22 Cyprian Kamil Norwid probably carried out a dialogue or even a polemic with Karol Libelt. In his Estetyka czyli Umnictwo Piękne Karol Libelt also considered the concepts of form and content, referring to beauty, good and truth, in a different way presenting their interdependencies. Beauty and truth together make good, according to Norwid, beauty and good join to make truth, or rather they are permeated with the light of both the Truth. This approach seems to be more consistent with the spirit of the Gospel - Christ says He is the truth. The truth is the crowning or even a complement, if we see it in the context of Norwid's reflections in his Fortepian Szopena [Chopin's Piano]. One could also find a reference of the idea of truth as light to the third Divine Person - the Holy Spirit. 
Theology of beauty

Norwid uses an intriguing word figuration. Shaping may be understood as figuration.

About profile we think mainly as a particular portrait development. One side of a face, drawn as a contour or as a shadow projected on a plane, tells much more about the portrayed person than the en face view. The profile, like fingerprints, allows identification, it is an individual, distinctive and unique trace.

Describing a profile requires stating the shape, every detail and element precisely. In architecture, but not only there, the profile may be a significant aspect which distinguishes the style, the epoch, artistic movements and even the author. Thus, the profile means the character, ability to distinguish or qualify. Metaphorically speaking, the profile is the name and identity.

The form in art is first of all a matrix, a pattern, a system of reference. It permits one to replicate, repeat, copy, develop or imitate. The form is an apposition, a finite and fully modelled shape. One might presume that in Norwid's concept the notion of matrix is the key one. In view of earlier philosophical deliberations over the form and its meaning, starting from Aristotle, such an approach could be considered as simplification, however, in the context of fine arts it is natural and justified.

Analysing the Creation in chapter 1 of the Genesis, we can watch the stages of the process of God's activity. Four stages of the process are described by short phrases:

"Let us make"(Gen 1, 26) - stage one - "In the beginning was the Word" (John 1, 1), God's intention, His will.

"And it was so"(Gen 1, 30) - stage two - "The Word became flesh"(John 1, 14). The world emerged from chaos, from non-existence, it received a shape. The idea was materialized, embodied, incarnated.

"God called"(Gen 1,5) - stage three - It means He gave a name and a name is identity. The shape was in a way perpetuated, intended to last, also the goal and the sense were defined. One might say that the shape was profiled.

"And God saw that it was good."(Gen 1, 12) - stage four - "And God saw that it was good. God blessed them and said, "Be fruitful and increase in number.»"(Gen 1,22). All creatures were given autonomy and a creative ability to prolong and continue the process of creation. God in His creative act defined the archetypes, original forms and the mechanism.

The artistic process may be viewed similarly, with all its stages.

Stage one: "In the beginning was the Word" - the artist's idea, impulse, intuition, intelligent project. 
Stage two: "the word became flesh" is the moment when the author touches the stone with a chisel, a metal slab with a graver, the canvas with a paintbrush. The effect of their work is a shape, which appears out of non-existence, a stone, clay, a labyrinth of lines on a plane, out of colourful blotches.

Stage three: is the moment when the shape is recognisable. It becomes a figure, portrait, object, architecture. The shape becomes recognised and named. Its individual characteristics are evident, its profile revealed. It gains a name and identity.

Stage four: the artist finishes the work, assesses it and decides if it is good, if it is as they intended it to be, as they were able to do it. The work becomes an autonomous composition and the artist can give it to the world, it will be judged, commented, interpreted, reproduced, copied, cropped. It becomes a form, a point of reference, a provocation for activities of the audience and critics. In the case of some art forms, especially sculpture and graphics as well as architecture and design, the work at this stage becomes literally a form, i.e. a matrix used to gain the final, material, noble form of the work of art.

In Norwid's concept the creative process appears as a reflection of the Creation. That act of the Divine Artist may be perceived as a matrix - a form, which the human being, the artist - the master of art fits in with their activity.

Jako więc prorok wychodząc z sumienia,

Prawdą dla prawdy gore

\section{w kształt płomienia}

Theology of beauty

Tak wieszcz z piękności wychodzi So a poet starts from the sense poczucia

(A piękność kształtem Prawdy i Miłości),

Więc od snowania wchadza do wysnucia,

Określa profil... stąd - zalet całości

Szukamy w wieszczu - stąd wszyscy wieszczowie

Rozpoczynali piękności podziwem; ${ }^{24}$
[Thus, as a prophet starting form the conscience, With truth, for truth burns like a flame

(And beauty is a shape of Truth

Starts from weaving and when and Love), has woven,

Defines the profile... therefore,

We seek virtues in a poet - and all poets

Started from adoring beauty;]

$24 \quad$ Norwid, C. K.: Promethidion, Wiestaw 128-135, p. 95. 
Theology of beauty

In this fragment Norwid shows the sequence of events which make a creative process and here the idea expressed by the poet about the conscience, where any creative thought starts, is confirmed. The idea begins from recognizing Beauty (and beauty is a shape of Truth and Love), from "the sense of beauty" but first of all from admiration of it. St. Augustine's admiration of Beauty so old and so new ${ }^{25}$ is known to the author of Promethidion. The admiration does not allow indifference, it is an imperative of creative activity, a personal response of the artist. If the prophet "with truth, for truth burns like a flame", then also an artist burns and annihilates themselves with beauty for Beauty.

In the Polish language the word „beauty” sounds like two other words and may even develop into a third one:

It consists of „pieśń” [a song] and ,jęk” [a groan], and makes yet another word „po-jęk-ność” [after-groan-ness], as if triumph over pain. ${ }^{26}$

The aspect of effort and work, struggle, perhaps even suffering and loneliness of the artist is significant and the poet emphasized it more than once. Understood by Norwid in the light of the Gospel, it ensures us that there is no triumph without pain, that resurrection does not exist without Golgotha. In order to achieve "freedom in God", as the poet confesses, ,one must first open one's way with a cross and painful struggle"27.

Norwid, presenting an artist's activity as a parallel of Creator's act, uses a reference to the artistic act also for two fundamental elements characteristic for the process. The first one is the tangible effect of an artistic work. The other - is the effort, the univocal, measurable effort fought with physical tiredness, which demonstrates the value and sacredness of work as a fruitful way, a way which leads to the goal ${ }^{28}$.

Bo piękno na to jest by zachwycało

Do pracy - praca by się zmartwychwstało ${ }^{29}$.
[Beauty is to delight

For work - and work - to make

one resurrect.]

The sacredness of art in Norwid's concept has a manifold dimension. Firstly, it comes from the source of Beauty, Good and Truth, from ingraining all creative activity in God the Creator. Secondly, it starts in the essence of an artistic process itself, when the artist fulfills a priestly mission and the process is perceived as a repetition, a reflection of

\footnotetext{
$25 \quad$ St. Augustine, Confessions, vol. X, ch. 27.

Norwid, C.K.: O sztuce (dla Polaków), [Of Art (for Polish People)] op. cit. p.373. 
God's act of creation, as the artist's participation in the mystery of creation. Finally, on account of the aim of art. The eventual aim of art, as the aim of life is resurrection and therefore achieving the fullness of cognition, not ,as in a mirror”, but face to face.

\section{STWÓRCA - TWÓRCA. NORWIDOWSKA KONCEPCJA PIĘKNA, SZTUKI I ARTYSTY, A PLASTYCZNY PROCES TWÓRCZY}

Chrześcijańska koncepcja piękna, sztuki, artysty sformułowana przez Cypriana Kamila Norwida i przedstawiona na kartach Promethidionu w wyraźny sposób Theology of beauty odwołuje się do doświadczenia sztuk pięknych. Odniesienie do plastycznego procesu twórczego w dużej mierze norwidowską koncepcję buduje i scala.

Dla sformułowania definicji piękna Norwid używa trzech określeń: kształt, profil i forma. W sztukach pięknych wspomniane hasła mają swoje specyficzne znaczenia, pozostają we wzajemnych relacjach definiując poszczególne etapy procesu twórczego. W koncepcji Norwida pojmowanie formy jako matrycy wydaje się szczególnie istotne i pozwala spojrzeć na ludzką twórczość jako odzwierciedlenie Boskiego aktu stwórczego. Człowiek stworzony na obraz i podobieństwo Boże stał się zdolny do twórczości. Zaproszony został do czynienia piękna i dobra, dzieki którym odkrywa i przybliża się do Boga, źródła wartości transcendentnych

Słowa kluczowe: piękno, dobro, prawda, miłość, sztuka, Stwórca, twórca, artysta, sztukmistrz, proces twórczy, kształt, profil, forma, matryca, powtórzenie, refleks, poznanie, zmartwychwstanie, tajemnica stworzenia, tajemnica wcielenia, podobieństwo Boże.

I stąd największym prosty lud poetą,

Co nuci z dłońmi ziemią brązowemi,

I stąd najlepszym Cezar historykiem,

Który dyktował z konia - nie przy biurze,

I Michał-Anioł, co kuł sam w marmurze...
[And thus, the greatest poet is the simplest people

Who hums and their hands brown with soil, (...)

And thus, the best historian is Caesar,

Who dictated from his horse, not desk,

And Michaelangelo, who chiseled marble on his own...]

(C.K. Norwid, Promethidion, Bogumit, 187-188 i 1193-195, p.80) The expression „on his own" in the quote above seems to be significant and it may be presumed that the poet did not use it accidentally, as it can be understood either as „with his own hands” or „alone”. Loneliness is associated with pain and self-reliance - with personal effort of work. 


\section{Bibliography:}

1. Halkiewicz-Sojak G., Norwidowskie metafory i definicje piękna, [Norwid's Metaphores and Definitions of Beauty] [in:] E. Nowicka i Z. Przychodniak (ed.), Piękno wieku dziewiętnastego. Studia i szkice z historii literatury $i$ estetyki, [Beauty in the $19^{\text {th }}$ Century] Poznań 2008.

2. Jan Paweł II, $Z$ poezji Norwida emanuje światto, [Norwid's poetry emanates light], a speech given to representatives of National Heritage Board of Poland on C.K. Norwid's180 th birth anniversary, http://www.opoka.org.pl/ zycie kosciola/ l'osservatore romano/ 9(236)2001/ kosciol w polsce. Html (10 Feb 2017)

3. Norwid C. K., List do Teofila Lenartowicza $z 16$ X 1868, Pisma wszystkie, [A Letter to Teofil Lenartowicz] worked out by J.W. Gomulicki, 1971-1976.

4. Norwid C. K., O sztuce dla Polaków, [Of Art for Polish People] Pisma Wybrane. Worked out by J.W. Gomulicki, PIW 1968.

5. Norwid C. K., Promethidion, Kraków 1997.

6. Norwid C. K., Rzecz o wolności stowa, [About Freedom of Speech].

7. Sawicki S., Sztuka - Bez granic. [Art - Without Borders] [in:] Norwid C. K., Promethidion, Kraków 1997.

8. Stownik Języka Polskiego [Polish Language Dictionary] PWN, Warszawa 1978.

9. St. Augustine, Confessions, vol. X, ch. 27. 